\title{
A survey of foliar mineral nutrient concentrations of Pinus canariensis at field plots in Tenerife
}

\author{
Michael Tausz ${ }^{\mathrm{a},{ }^{*}}$, Walter Trummer ${ }^{\mathrm{a}}$, Astrid Wonisch ${ }^{\mathrm{a}}$, Walter Goessler ${ }^{\mathrm{b}}$, \\ Dieter Grill $^{\mathrm{a}}$, Maria Soledad Jiménez ${ }^{\mathrm{c}}$, Domingo Morales ${ }^{\mathrm{c}}$ \\ ${ }^{a}$ Institut für Pflanzenphysiologie, Karl-Franzens Universität Graz, Schubertstraße 51, A-8010 Graz, Austria \\ ${ }^{\mathrm{b}}$ Institut für Chemie, Karl-Franzens Universität Graz, Analytische Chemie, Universitätsplatz 1, A-8010 Graz, Austria \\ ${ }^{\mathrm{c}}$ Departamento de Biología Vegetal, Universidad de La Laguna, Fisiología Vegetal, E-38207 La Laguna, Tenerife, Spain
}

Received 22 July 2002; received in revised form 17 June 2003; accepted 14 July 2003

\begin{abstract}
The foliar concentrations of the macronutrients $\mathrm{Mg}, \mathrm{Ca}, \mathrm{K}, \mathrm{N}$, and $\mathrm{P}$ and the micronutrients $\mathrm{Fe}, \mathrm{Mn}, \mathrm{B}, \mathrm{Cu}, \mathrm{Mo}$, and $\mathrm{Zn}$ were measured in field grown Pinus canariensis trees. Plots were chosen all over the range of this species in Tenerife to establish a survey of the nutrient concentrations. Compared to available data from related pine species ( $P$. halepensis, $P$. pinaster, $P$. radiata) $P$. canariensis needles had lower $\mathrm{N}$ and $\mathrm{P}$ concentrations, higher $\mathrm{Ca}$ and $\mathrm{Mg}$, and about equal $\mathrm{K}$ concentrations. $\mathrm{N} / \mathrm{nutrient}$ ratios were in the range considered optimal for pine species. Micronutrients were in the range considered adequate for pines except for low $\mathrm{Cu}$ values.
\end{abstract}

(C) 2003 Elsevier B.V. All rights reserved.

Keywords: Mineral nutrition; Foliar nutrient concentrations; Magnesium; Calcium; Nitrogen; Phosphorus; Potassium; Micronutrients

\section{Introduction}

The foliar mineral nutrient concentrations of trees are important parameters to assess the nutritional status of forests (Gussone, 1964; Marschner, 1995). Nutritionally caused growth restrictions and mineral deficiencies are detectable by comparing foliar nutrient concentrations to threshold ranges. In particular, for forest trees tissue analyses provide an accurate reflection of the nutritional status whereas the value of soil analysis is limited (Marschner, 1995). Foliar

\footnotetext{
* Corresponding author. Present address: Forest Science Centre, Water Street, Creswick, Vic. 3363, Australia.

Tel.: +61-3-5321-4300; fax: +61-3-5321-4166.

E-mail address: michael.tausz@uni-graz.at (M. Tausz).
}

nutrient analyses are included in the two European scale forest survey programs "The International Cooperative Programme on Assessment and Monitoring of Air Pollution Effects on Forests (ICP Forests)" (UN/ECE, 2000) and the "European Union Scheme on the Protection of Forests against Atmospheric Pollution (EU Forestry measures)" (EU-Regulation No. 3528/86) where the main European forest species are continually monitored at selected sites. The data are collected all over Europe and published in the FFCC (Forest Foliar Coordination Center located at the Federal Forest Research Center, Vienna, Austria, Stefan et al., 2000). However, these European scale programs concentrate on main forest species and exclude other tree species of more local importance, such as the Canarian pine species, Pinus canariensis Chr. Sm. ex Spreng. 
P. canariensis is endemic to the Canary Islands where it mainly forms monospecific forests under widely different ecological conditions (Blanco et al., 1989). The distribution limit of this species in Tenerife ranges from about 500 to $2500 \mathrm{~m}$ above sea level on the south facing slopes of the island and from 800 to $2200 \mathrm{~m}$ on the northern slopes (Del Arco Aguilar et al., 1992). The southern pine forests are exposed to very dry, partly semi-arid climates whereas the northern pine forests experience frequent fog impacts and, consequently, more humid conditions (Rothe, 1996). At the high altitude plots, the trees experience regular winter frosts. These pine forests ("pinares") are essential for the local forestry and contribute strongly to the water balance of the islands by filtration of horizontal deposition and by providing protection from erosion (Meusel, 1965). In addition to the importance in its native range, $P$. canariensis is successfully used as a commercial forest tree mainly in North and South Africa, and, to some extent, also in South America, Australia, and New Zealand (Stephan, 1995). Furthermore, it is commonly planted as an ornamental tree in warm climates. Due to its wide ecological amplitude and its high timber quality (Climent et al., 1998; Stephan, 1995) it has a strong potential as forest tree also in other countries. Despite this widely acknowledged importance a substantial lack of data on this species exists in the literature. An extensive literature overview on foliar nutrient data of pine species showed that little was known about $P$. canariensis (Fürst, 1997). Only one small-scale study on one elevational transect at the south of Tenerife has been carried out (Tausz et al., 1998).

The objective of the present study was to develop a representative survey of foliar nutrient concentrations of $P$. canariensis in its (natural and afforested) distribution range in Tenerife. By sampling plots distributed throughout the island, the normal range of foliar nutrients is established, which is a necessary prerequisite to evaluate nutrient status of this species.

\section{Materials and methods}

\subsection{Sampling plots}

Fifty-five plots were selected in the pine forest regions of Tenerife, distributed as evenly as possible
(Fig. 1). Plots were intended to be representative for the respective area. On a sub-set of these points, micronutrient analysis was also conducted (Fig. 1).

At each plot, pine stands were characterized recording tree heights, age, diameters, and crown conditions (according to Cadahia et al., 1991). Ecologically, stands vary widely according to elevation and climatic zone (Blanco et al., 1989). Four different zones largely representing different ecological pine forest types, could be distinguished (NE, NW, S, SW in Fig. 1). In the $S$ zones, natural, very dry pine forests on shallow soils dominate, in NW mainly higher elevated, partly more humid plots are located, whereas in NE and NW plots pine forests are mostly planted, and receive more frequent precipitation and fogs (in the NW more than in NE). Generally, low elevated plots are drier, and high elevated plots more humid.

\subsection{Plant material}

The sampling procedures were closely based on those recommended by the ICP Forests (Stefan et al., 2000). Three $P$. canariensis trees per plot were sampled in August 1998. ICP Forests guidelines suggest sampling of evergreen species during "dormancy period" (Stefan et al., 2000). Since strict dormancy periods hardly exist under the climatic conditions of Tenerife, the period towards the end of seasonal summer drought (August) is the best approximation. The sampled trees were dominant or, since stands were mostly open, of average height relative to the stand. First order lateral twigs were pruned on light exposed crown positions at $5 \mathrm{~m}$ height with pole pruners. It was technically not possible in this study to take samples from top canopy level (as suggested by Stefan et al., 2000), but in open canopy stands lower to mid-canopy is regarded an acceptable alternative. Wherever possible, fully developed, mature needles of the youngest and previous season's flush were collected and oven-dried at $80{ }^{\circ} \mathrm{C}$. Since $P$. canariensis needles may grow during the whole season, at few plots it was inevitable to sample needles of the youngest age class, which were not fully elongated. The guidelines of ICP Forests allow sampling of such needles for comparable species (Stefan et al., 2000).

The needles were powdered in a laboratory mill (Analysenmühle A10, Janke and Kunkel, Germany) and the powder stored over silica gel until extraction. 


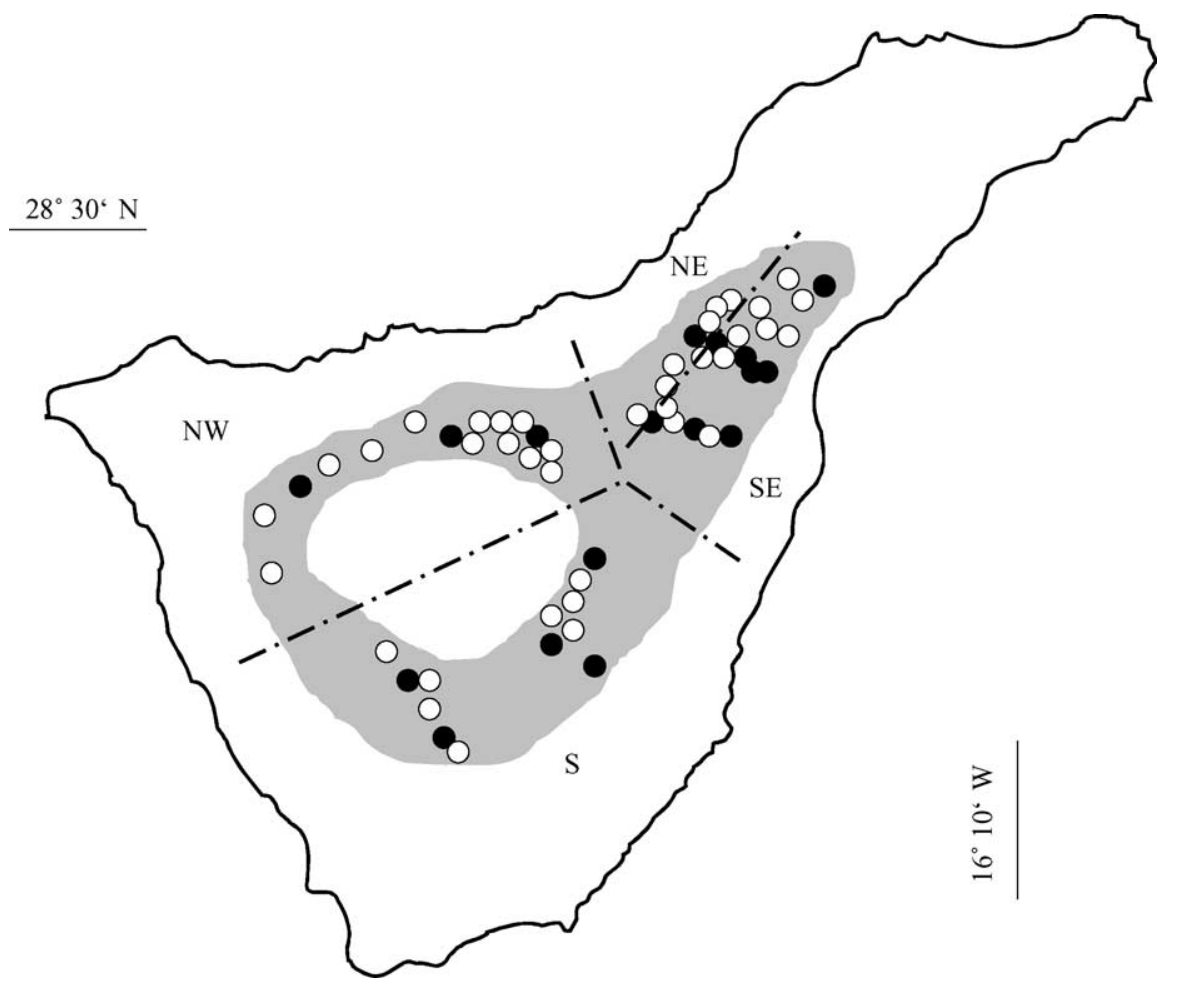

Fig. 1. Plots sampled for P. canariensis needles in Tenerife island. Shaded area: distribution of P. canariensis forest in Tenerife; filled symbols: sub-sample investigated also for micronutrients; regions (S, SE, NE, NW) discussed in the text are indicated.

For each needle age class separately, subsamples of each tree per plot were combined for one mixed sample per plot.

\subsection{Cation determination $(K, C a, M g)$}

The extracts were prepared by wet digestion in $\mathrm{H}_{2} \mathrm{SO}_{4}$ and $\mathrm{HNO}_{3}$. The $2.5 \mathrm{ml} 65 \%$ (w/w) $\mathrm{HNO}_{3}$ and $6 \mathrm{ml} \mathrm{H}_{2} \mathrm{SO}_{4}(96-98 \%$, w/w) were used for $500 \mathrm{mg}$ sample powder. Extraction was carried out in a digestor (Digestor 430, Büchi, Switzerland) until extracts were clear and colorless. The extract was adjusted to $50 \mathrm{ml}$ with double distilled water (Urbach et al., 1976).

The cations were determined by atomic absorption spectroscopy (AAS 5 FL, Zeiss, Germany).

\subsection{Phosphorus determination}

Phosphorus was measured photometrically on the same extract used for cation determination (see above) (Schinner et al., 1993).

\subsection{Nitrogen determination}

Nitrogen determination was done by a standard Kjeldahl procedure (Büchi, Switzerland). Procedures for $\mathrm{Mg}, \mathrm{Ca}, \mathrm{K}, \mathrm{N}$, and $\mathrm{P}$ determinations were evaluated using certified standard samples (beech leaves No. 215, Standard Reference Material 100, EC Bureau of Reference; spruce needles No. 70, Standard Reference Material 101, EC Bureau of Reference; and citrus leaves No. 1572, Standard Reference Material des US Department of Commerce).

\subsection{Micronutrient analyses}

For the determinations of the micronutrients $(\mathrm{Fe}, \mathrm{B}$, $\mathrm{Mo}, \mathrm{Cu}, \mathrm{Mn}, \mathrm{Zn}) \sim 300 \mathrm{mg}$ were weighed to $0.1 \mathrm{mg}$ into the $12 \mathrm{ml}$ quartz digestion vessels of the microwave assisted heating autoclave UltraCLAVE 2 (EMLS, Leutkirch, Germany). After addition of $5.0 \mathrm{ml}$ sub-boiled nitric acid, the vessels were closed with Teflon cups, placed in the quartz rack and the rack 
was mounted in the UltraCLAVE 2. Thereafter the system was loaded with argon to a final pressure of $40 \mathrm{bar}$. The heating program was ramped to $250{ }^{\circ} \mathrm{C}$ within $40 \mathrm{~min}$ and then the temperature was kept at $250{ }^{\circ} \mathrm{C}$ for $30 \mathrm{~min}$. After cooling the samples were quantitatively transferred into $50.0 \mathrm{ml}$ polyethylene tubes.

An Agilent 4500 inductively coupled plasma mass spectrometer (Agilent, Waldbronn, Germany), equipped with a Babington-type nebulizer was used for the determination of the micronutrients. Quantification was performed with external calibration curves in the appropriate concentration ranges. For quality control NIST SRM 1575 Pine Needles (National Institute of Standards and Technology, Gaithersburg, USA) were mineralized and analyzed in the same way.

\subsection{Statistics}

Differences between needle age classes were tested by Wilcoxon's two sample test. Differences between geographic regions (Fig. 1) were evaluated by a one-way ANOVA followed by LSD test. Correlations between age classes or between nutrient concentrations and environmental factors were evaluated by Spearman's $\rho$ rank correlation coefficient.

\section{Results}

Table 1 shows the macronutrient concentrations of field grown $P$. canariensis needles collected at 55 plots. Previous year's needles contained significantly higher concentrations of calcium and lower concentrations of potassium than current season's needles. There were no significant differences between needle age classes for Mg, N, and P. Except for Mg concentrations (Spearman's $\rho=-0.01$ ), data of current and previous year's flush were significantly correlated (Spearman's $\rho$ for Ca $0.56, \mathrm{~K} 0.46, \mathrm{~N} 0.52$, P 0.61 ; all significant at $P<0.001)$.

Corresponding to the low nitrogen levels, nitrogenrelevant nutrient ratios were in the range considered well balanced or below (Table 2).

In Table 3, micronutrient concentrations of $P$. canariensis needles from a sub-set of 18 plots are shown. In this data set, all micronutrient concentrations were highly correlated between current and previous year's needles (Spearman's $\rho \geq 0.82$, all significant at $P<0.001$ ). Differences between needle age classes were not found.

Significant differences in the mean nutrient concentrations among the different regions of the island (profiles, Fig. 1) were only found for $\mathrm{Mg}$ in both needle age classes and for $\mathrm{P}$ in the younger needle age class. P concentrations were highest in the samples from the $\mathrm{NE}$ part and lowest in the $\mathrm{S}$ plots. $\mathrm{Mg}$ concentrations were distinct in the SE part with lower values in young and higher values in 1-year-old needles. Only in this group of plots a significant increase of $\mathrm{Mg}$ from younger to older needles was found (data not shown).

In micronutrient analysis, iron concentrations were significantly lower in previous year's needles from the NW profile. Only one plot was investigated from the NE part (and not included in the statistical treatment), but these needles (both age classes) showed maximum Mn concentrations of accounting for a good part of the high variation in Mn (Table 3).

Table 1

Foliar macronutrient concentrations $\left(\mathrm{mg} \mathrm{g}^{-1} \mathrm{dw}\right)$ of $P$. canariensis needles sampled at 55 plots in Tenerife

\begin{tabular}{|c|c|c|c|c|c|c|c|c|c|c|c|c|c|}
\hline & \multicolumn{5}{|c|}{ Current year's needles } & \multicolumn{5}{|c|}{ Previous year's needles } & \multicolumn{3}{|c|}{ Adequate ranges ${ }^{\mathrm{a}}$} \\
\hline & $\begin{array}{l}25 \text { th } \\
\text { percentile }\end{array}$ & Median & $\begin{array}{l}\text { 75th } \\
\text { percentile }\end{array}$ & Mean & S.D. & $\begin{array}{l}25 \text { th } \\
\text { percentile }\end{array}$ & Median & $\begin{array}{l}\text { 75th } \\
\text { percentile }\end{array}$ & Mean & S.D. & P. pinaster & P. halepensis & P. radiata \\
\hline K & 8.66 & 9.48 & 10.35 & 9.63 & 1.73 & 5.28 & $6.18^{\mathrm{b}}$ & 7.02 & 6.10 & 1.02 & 3 to $>5$ & $>8$ & $3-7$ \\
\hline $\mathrm{Ca}$ & 2.47 & 3.01 & 4.64 & 3.43 & 1.39 & 5.69 & $8.93^{\mathrm{b}}$ & 12.05 & 9.11 & 4.16 & $1.6-2.7$ & $3-6$ & $1-4$ \\
\hline $\mathrm{Mg}$ & 1.23 & 1.44 & 1.70 & 1.48 & 0.32 & 1.27 & 1.58 & 1.83 & 1.58 & 0.44 & $0.5-2$ & $1-1.9$ & $0.7-2.4$ \\
\hline $\mathrm{N}$ & 7.13 & 8.50 & 10.06 & 8.73 & 2.43 & 7.10 & 8.65 & 10.68 & 8.95 & 2.19 & $9-15$ & $10-20$ & $12-15$ \\
\hline $\mathrm{P}$ & 0.95 & 1.13 & 1.34 & 1.17 & 0.25 & 0.80 & 1.07 & 1.49 & 1.24 & 0.65 & $0.9-1.5$ & $1-2$ & 1.2 to $>1.4$ \\
\hline
\end{tabular}

\footnotetext{
${ }^{\text {a }}$ Reported in Fürst (1997) and Bergmann (1993).
}

${ }^{\mathrm{b}}$ Significant differences between needle age classes. 
Table 2

Nutrient ratios, medians and percentiles of 55 plots in Tenerife

\begin{tabular}{|c|c|c|c|c|c|c|c|}
\hline & \multicolumn{3}{|c|}{ Current year's needles } & \multicolumn{3}{|c|}{ Previous year's needles } & \multirow{2}{*}{$\begin{array}{l}\text { Well-balanced } \\
\text { range }^{\text {a }}\end{array}$} \\
\hline & 25th percentile & Median & 75th percentile & 25 th percentile & Median & 75th percentile & \\
\hline $\mathrm{N} / \mathrm{K}$ & 0.72 & 0.91 & 1.05 & 1.19 & 1.43 & 1.72 & $1-3$ \\
\hline $\mathrm{N} / \mathrm{Ca}$ & 1.88 & 2.66 & 3.27 & 0.70 & 1.01 & 1.66 & $2-7$ \\
\hline $\mathrm{N} / \mathrm{Mg}$ & 4.36 & 5.82 & 7.09 & 4.48 & 5.73 & 7.03 & $8-14$ \\
\hline $\mathrm{N} / \mathrm{P}$ & 6.11 & 7.33 & 8.93 & 5.34 & 8.53 & 12.21 & $7-10$ \\
\hline
\end{tabular}

${ }^{\text {a }}$ Reported in Stefan and Fürst (1998).

Table 3

Micronutrient concentrations $\left(\mathrm{g}^{-1} \mathrm{dw}\right)$ of $P$. canariensis needles sampled at 18 plots in Tenerife

\begin{tabular}{|c|c|c|c|c|c|c|c|c|c|c|c|c|c|}
\hline & \multicolumn{5}{|c|}{ Current year's needles } & \multicolumn{5}{|c|}{ Previous year's needles } & \multicolumn{3}{|c|}{ Adequate ranges } \\
\hline & $\begin{array}{l}\text { 25th } \\
\text { percentile }\end{array}$ & Median & $\begin{array}{l}\text { 75th } \\
\text { percentile }\end{array}$ & Mean & S.D. & $\begin{array}{l}\text { 25th } \\
\text { percentile }\end{array}$ & Median & $\begin{array}{l}\text { 75th } \\
\text { percentile }\end{array}$ & Mean & S.D. & P. pinaster ${ }^{\mathrm{a}}$ & P. halepensis ${ }^{\mathrm{a}}$ & P. radiata $^{\mathrm{b}}$ \\
\hline $\mathrm{Fe}(\mu \mathrm{g})$ & 443 & 557 & 719 & 637 & 288 & 443 & 563 & 684 & 620 & 270 & & & \\
\hline $\mathrm{B}(\mu \mathrm{g})$ & 14.2 & 19.5 & 30.1 & 24.3 & 11.4 & 13.9 & 19.1 & 30.9 & 23.7 & 10.6 & 16 & $>10$ & $10-15$ \\
\hline Mo (ng) & 35 & 91 & 153 & 154 & 211 & 36 & 90 & 135 & 148 & 200 & & - & $80-300$ \\
\hline $\mathrm{Cu}(\mu \mathrm{g})$ & 1.93 & 2.48 & 3.04 & 2.55 & 0.75 & 1.84 & 2.40 & 2.87 & 2.44 & 0.69 & $6-31$ & $6-10^{\mathrm{c}}$ & $4-10$ \\
\hline $\mathrm{Mn}(\mu \mathrm{g})$ & 104 & 229 & 313 & 244 & 258 & 100 & 225 & 309 & 306 & 258 & & $30-470$ & $50-500$ \\
\hline $\mathrm{Zn}(\mu \mathrm{g})$ & 20 & 33 & 39 & 31 & 11 & 21 & 32 & 39 & 31 & 11 & & - & $20-50$ \\
\hline
\end{tabular}

${ }^{\mathrm{a}}$ Reported in Fürst (1997).

${ }^{\mathrm{b}}$ Reported in Bergmann (1993).

${ }^{\mathrm{c}}$ Only data for pot trials were available.

Correlations of foliar macronutrients with elevation (which in Tenerife is a good measure of proximity to sea) gave no indication that sea sprays had a direct impact. Nitrogen and potassium were unrelated to elevation, whereas calcium (Spearman's $\rho=0.46$, $P<0.001)$, magnesium $(\rho=0.40, P=0.003)$, and phosphorus ( $\rho=0.33, P=0.013)$ in current season's needles were even positively related to elevation. Only Mg in previous year's needles showed a significant negative correlation to elevation $(\rho=-0.39$, $P=0.004$ ). Among the micronutrients investigated here, only Mo showed a significant correlation with elevation (current needles $\rho=-0.63, P=0.005$; previous year's needles $\rho=-0.62, P=0.007$ ).

Needles grown in closer vicinity $(<50 \mathrm{~m})$ to main roads had significantly higher nitrogen concentrations $(P<0.05)$ than needles from trees growing further away. Significant influences on other investigated elements were not found. Variations in tree age, tree height, diameters, and crown condition (classified according to Cadahia et al., 1991) were not related to foliar nutrient concentrations in the present data set.

\section{Discussion}

The most closely related pine species to $P$. canariensis is considered to be $P$. roxburghii Sargent from Asia, but foliar nutrient data for this species were also not available (Fürst, 1997). The next most closely related species for which foliar nutrient data were found are Spanish Mediterranean pine species, P. halepensis and P. pinaster (Stephan, 1995). Data for these species in continental Europe are reported in the Forest Foliar Coordinating Center (FFCC), and have also been assessed in many previous studies (reported in Fürst, 1997; Bergmann, 1993). Another possible comparative species is $P$. radiata (Mesanza et al., 1993), because it has been extensively planted in Tenerife.

Compared to those species, nitrogen levels in P. canariensis foliage in Tenerife are consistently low (Table 1). Average values for pines in peninsular Spain (where $P$. canariensis does not naturally occur) are $12 \mathrm{mg} \mathrm{g}^{-1}$ (but ranging from 7.6 to 18.0). In the FFCC database nitrogen concentrations below 
$12 \mathrm{mg} \mathrm{g}^{-1}$ are classified in the lowest of three classes for pine species. Only the upper quartile of all trees in the present data reached that threshold (Table 1). Apart from possible species characteristics, low $\mathrm{N}$ values may reflect general limitations at investigated plots. At nearly all locations, pine litter ("pinocha") is removed on a regular basis due to a traditional local practice, which helps to decrease wildfire risk (removal of fuel), but may lead to some nutrient depletion. Plots near to main roads (a potential $\mathrm{N}$ source) have slightly higher $\mathrm{N}$ concentrations, indicating a higher potential for $\mathrm{N}$ uptake.

Median $\mathrm{P}$ concentrations are also low in comparison, i.e. more than $25 \%$ of all plots would be classified in the lowest class according to FFCC $\left(<1 \mathrm{mg} \mathrm{g}^{-1} \mathrm{dw}\right.$, Fürst, 2002). Volcanic soils in Tenerife are known for their high $\mathrm{P}$ fixation capacity (Jiménez et al., 1993), which may contribute to low $P$ availability to trees.

With respect to cations, the upper quartile for $\mathrm{Ca}$ and the median $\mathrm{Mg}$ concentrations of the $P$. canariensis data set would be classified as the highest class according to the FFCC rule ( $>4.0 \mathrm{mg} \mathrm{g}^{-1}$ for $\mathrm{Ca}$ and $>1.5$ for $\mathrm{Mg}$ ). The potassium concentrations are in the medium range.

The micronutrient concentrations are mostly within adequate ranges published for other pine species. Copper alone is a little lower than the reported adequate ranges for $P$. halepensis, $P$. pinaster, and $P$. radiata (Table 2).

The foliar nutrient concentrations reflect the nutritional status of trees (Mengel and Kirkby, 2001) which is the result of many environmental factors, such as soil properties, season length, water supply, and other environmental factors. The volcanic bedrocks and soils in Tenerife are highly variable, but generally rich in $\mathrm{Ca}, \mathrm{Mg}$, and $\mathrm{K}$ (Rothe, 1996). The plots investigated in the present study have generally shallow soils and tree roots lead deep into the bedrock. P. canariensis roots can be seen more than $15 \mathrm{~m}$ deep at some road banks. Adequate soil sampling to test nutrient availability in such soils is a highly complex problem, and foliar nutrient data are better integrative indicators to assess the nutritional status of trees (Marschner, 1995).

Differences between zones (NE, SE, NW, S) in the present data set reflect differences in ecological conditions. Humidity on Tenerife island is governed by regular tradewinds bringing clouds and precipitation predominately to the plots in the zones NE and SE, and leaving $\mathrm{S}$ sites driest. However, resulting differences in needle nutrient concentrations were not very prominent.

In a previous small-scale study, $\mathrm{NaCl}$ concentrations were determined (Tausz et al., 1998). They were strongly negatively correlated to elevation, and significant sea spray input up to $1000 \mathrm{~m}$ was shown in that paper. In the present data, correlations of nutrient concentrations with elevation were scarce and most were even positive, indicating higher concentrations at higher elevated plots. The latter may mainly reflect the generally more humid conditions at higher elevated plots allowing a higher uptake as opposed to dry conditions at low elevation plots. Only Mo was related to elevation in a way that suggests sea input at lower elevated plots.

In the present work growth analyses of the investigated pine stands were not performed. A crown condition classification according to criteria given in Cadahia et al. (1991) for other Mediterranean pine species did not indicate any relation to foliar nutrient concentrations (data not shown). The nutrient concentration ranges described here provide a baseline survey of normal values at natural, vital stands, but are not directly applicable as an assessment of critical concentrations for optimal growth.

\section{Acknowledgements}

The research was supported by the "Wissenschaftlich-technische Zusammenarbeit ÖsterreichSpanien", and by a guest professorship of M. Tausz in La Laguna financed by an agreement of the Universidad de La Laguna and the Banco Santander.

\section{References}

Bergmann, W., 1993. Ernährungsstörungen bei Kulturpflanzen. Gustav Fischer Verlag, Jena.

Blanco, A., Castroviejo, M., Fraile, J.L., Ganduillo, J.M., Muñoz, L.A., Sanchez, O., 1989. Estudio ecologico del pino canario. ICONA, Instituto Nacional para la Conservación de la Naturaleza, Madrid.

Cadahia, D., Cobos, J.M., Soria, S., Clauser, F., Gellini, R., Grossoni, P., Ferreira, M.C., 1991. Oservação de danos em espécies florestais mediterrâneas. Grafur S.A., Madrid. 
Climent, J., Gil, L., Pardos, J.A., 1998. Xylem anatomical traits related to resinous heartwood formation in Pinus canariensis Sm. Trees 12, 139-145.

Del Arco Aguilar, M.J., Pérez de Paz, P.L., Rodríguez, O., Salas, M., Wildpret, W., 1992. Atlas cartográfico de los pinares de Canarias. II. Tenerife. Dirección General de Medio Ambiente y Conservación de la Naturaleza, Gobierno de Canarias, Santa Cruz de Tenerife.

Fürst, A., 1997. Literaturübersicht: Nährstoffdaten Koniferen. Austrian Federal Forest Research Centre, Vienna.

Fürst, A., 2002. Classification values for European foliar data. Forest Foliar Coordination Centre, Forstliche Bundesversuchsanstalt, Wien. http://fbva.forvie.ac.at/600/1128.html.

Gussone, H.A., 1964. Faustzahlen für Düngung im Walde. BLV Bayrischer Landwirtschaftsverlag, München.

Jiménez, E.I., García, V.P., Espino, M., Moreno, J.M.H., 1993. City refuse compost as a phosphorus source to overcome the P-fixation capacity of sesquioxide-rich soils. Plant Soil 148, 115-127.

Marschner, H., 1995. Mineral Nutrition of Higher Plants, 2nd ed. Academic Press, London.

Mengel, K., Kirkby, E.A., 2001. Principles of Plant Nutrition, 5th ed. Kluwer Academic Publishers, Dordrecht.

Mesanza, J.M., Casado, H., Castillo, F.J., 1993. Nutrient concentrations in Pinus radiata D. Don needles in the Basque Country (Spain): a preliminary classification of parameters and sites. Ann. Sci. For. 50, 23-36.

Meusel, H., 1965. Die Reliktvegetation der Kanarischen Inseln in ihren Beziehungen zur süd- und mitteleuropäischen Flora. In: Gersch, M. (Ed.), Gesammelte Vorträge über moderne
Probleme der Abstammungslehre. Vol. 1. Friedrich-Schiller Universität, Jena, pp. 117-136.

Rothe, P., 1996. Kanarische Inseln. 2. Auflage. Sammlung geologischer Führer 81. Bornträger, Berlin.

Schinner, F., Öhlinger, R., Kandeler, E., Margesin, R., 1993. Bodenbiologische Arbeitsmethoden. 2. Aufl. Springer, Berlin.

Stefan, K., Fürst, A., 1998. Indication of S and N inputs by means of needle analyses based on the Austrian bio-indicator grid. Environ. Sci. Pollut. Res. 1, 63-69 (special issue).

Stefan, K., Fürst, A., Hacker, R., Bartels, U., 2000. 1997: Forest foliar condition in Europe-results of large-scale foliar chemistry surveys. UN/ECE, Austrian Federal Forest Research Centre, Vienna.

Stefan, K., Raitio, H., Bartels, U., Fürst, A., 2000. Manual on Methods and Criteria for Harmonized Sampling, Assessment, Monitoring and Analysis of the Effects of Air Pollution on Forests. Part IV. Sampling and Analysis of Needles and Leaves. UN/ECE, Austrian Federal Forest Research Centre, Vienna.

Stephan, B.R., 1995. Pinus canariensis. In: Schütt, P., Schuck, H.J., Lang, U.M., Roloff, A. (Eds.), Enzyklopädie der Holzgewächse. Handbuch und Atlas der Dendrologie. 2. ErgänzungsLieferung 10/95. Ecomed, Landsberg am Lech.

Tausz, M., Peters, J., Jiménez, M.S., Morales, D., Grill, D., 1998. Element contents and stress-physiological characterization of Pinus canariensis needles in Mediterranean type field stands in Tenerife. Chemosphere 36, 1019-1023.

UN/ECE, 2000. Strategy of ICP Forests for the period of 20012006. UN/ECE, Geneva.

Urbach, W., Rupp, W., Sturm, H., 1976. Experimente zur Stoffwechselphysiologie der Pflanzen. Georg Thieme Verlag, Stuttgart. 